Marquette University

e-Publications@Marquette

College of Education Faculty Research and

Publications

Education, College of

$1-1-2006$

\title{
After the In-Service Course: Challenges of Technology Integration
}

Gregory Robert Frederick

Marquette University, gregory.frederick@marquette.edu

Heidi Schweizer

Marquette University, heidi.schweizer@marquette.edu

Robert Lowe

Marquette University, robert.lowe@marquette.edu

Accepted version. Computers in the Schools, Vol. 23, No. 1-2 (September 08, 2006): 73-84. DOI. (C) 2006 Taylor \& Francis (Haworth Press). Used with permission. 


\title{
After the In-Service Course: Challenges of Technology Integration
}

\author{
Gregory R. Frederick \\ Educational Opportunity Program, Marquette University \\ Milwaukee, WI \\ Heidi Schweizer \\ School of Education, Marquette University \\ Milwaukee, WI \\ Robert Lowe \\ Department of Educational Policy and Leadership Studies, \\ Marquette University \\ Milwaukee, WI
}

This case study chronicles one teacher's experience in the semester after an in-service course, Using Technology for Instruction and Assessment. Results suggest that success in the course and good intentions do not necessarily translate into dramatic change in methods or media of instruction. Student mobility and special needs, unexpected administrative mandates, the anxiety of being judged as competent based on standardized test results, poorly designed classrooms, insufficient time to master new software, and habitual ways of conceptualizing what and how students should learn-all complicate efforts to help students use computers to construct meaning and represent their learning to others. Certainly, a professional development course is just one variable in a complex equation which has, as its solution, transformative teaching.

Computers in the Schools, Vol. 23, No. 1-2 (September 08, 2006): pg. 73-84. DOI. This article is (C) Taylor \& Francis (Routledge) and permission has been granted for this version to appear in e-Publications@Marquette. Taylor \& Francis (Routledge) does not grant permission for this article to be further copied/distributed or hosted elsewhere without the express permission from Taylor \& Francis (Routledge). 
Using Technology for Instruction and Assessment, an online, three-credit, graduate course completed by more than 700 teachers over a five-year period, was a professional development initiative between a large urban school district and a private university located within its boundaries. The course, funded through a Technology Literacy Challenge Fund grant, was designed to challenge $\mathrm{K}-12$ teachers' thinking about the integration of technology into their instruction. Course designers hoped that once these in-service teachers experienced social constructivist learning, collaborative groups, and performance-based assessment firsthand, they would be more likely to transfer these principles to their own practice (Schweizer, Whipp, \& Hayselett, 2002; Whipp \& Schweizer, 2001).

Survey results provide evidence of participants' overwhelming satisfaction with the course as well as abundant testimony to its lasting influence on their teaching practices (Middlebrooks, 2002). However, the results of this qualitative study of one teacher's experience in the semester after completing the course suggest that satisfaction with the in-service course and good intentions do not necessarily translate into dramatic change in the methods or media of instruction. Making the pedagogical shift from the traditional, teachercentered model of knowledge transmission to a more technology-rich, student-centered, inquiry-based classroom is a complex process. Wellplanned and well-received professional development initiatives, by themselves, do not guarantee dramatic change (Handler \& Strudler, 1997; Roblyer \& Edwards, 2000; Sheingold \& Hadley, 1990; Schrum, 1999).

In our case study of one fourth-grade teacher's practice, we ask: How is technology used for instruction and assessment?

\section{Methods}

Data for this case study were collected between May 7, 2001, and March 5, 2002. Two subjects were selected as primary informants from among several in-service teachers whom instructors recommended as particularly successful participants in the course. Anne and Lucy, colleagues at an urban elementary school, were first interviewed on the night they demonstrated their final project to their

Computers in the Schools, Vol. 23, No. 1-2 (September 08, 2006): pg. 73-84. DOI. This article is (C) Taylor \& Francis (Routledge) and permission has been granted for this version to appear in e-Publications@Marquette. Taylor \& Francis (Routledge) does not grant permission for this article to be further copied/distributed or hosted elsewhere without the express permission from Taylor \& Francis (Routledge). 
online classmates and other teachers enrolled in other sections of the graduate course. They were interviewed together again in August, just before classes began at the public elementary school where Lucy teaches fourth grade and Anne is a special education teacher. Each was interviewed individually again in November, and Lucy again in March of 2002. Between September 2001 and January 2002, Anne's classroom was observed seven times and Lucy's ten. Three of Lucy's male students participated in a joint interview in February of 2002, and the principal and the computer lab supervisor were interviewed separately on March 5. Transcripts of all interviews and of reflections on classroom observations were analyzed and coded for themes.

Researchers met frequently to discuss and analyze data. Themes that emerged from this ongoing analysis were classified as "challenges to technology integration." Of these, the following nine particular challenges surfaced, with varying degrees of significance: student mobility, students with special needs, low-expectations, unexpected administrative mandates, lack of teacher collaboration, anxiety of being judged as competent based on standardized test results, poorly designed classrooms, insufficient time to master new software, and habitual ways of conceptualizing what and how students should learn. All nine of these challenges presented themselves in Lucy's experiences as a fourth-grade teacher. As a result, we elected to focus on Lucy's practice in the presentation of this case.

Additional data included samples of student work and class handouts, field notes, a transcript of Anne and Lucy's contributions to the online course, and more than 100 digital photographs of Lucy's and Anne's classrooms and students, a computer lab, and various shots of the school building. All names are pseudonyms.

\section{The In-Service Course}

When special education teacher Anne Paulson alerted her fellow teachers at First Street Elementary that they were eligible to register for a free graduate course offered online by a major, private university, Lucy Moore was the only First Street teacher, besides Anne, who enrolled in the three-credit course, Using Technology for Instruction and Assessment. Their final project, an integrated reading

Computers in the Schools, Vol. 23, No. 1-2 (September 08, 2006): pg. 73-84. DOI. This article is (C) Taylor \& Francis (Routledge) and permission has been granted for this version to appear in e-Publications@Marquette. Taylor \& Francis (Routledge) does not grant permission for this article to be further copied/distributed or hosted elsewhere without the express permission from Taylor \& Francis (Routledge). 
lesson, built around the Judy Blume book, Freckle Juice, offered students multiple ways of demonstrating their learning to their teachers, their classmates, and other First Street students and staff. All students word-processed summaries of the book, and all were required to select at least one creative way of representing their understanding of some aspect of the book. These options included creating slide presentations, book jackets, crossword puzzles, or various alternative texts-from research reports to advertising posters and new chapters. The technology students could use to complete these projects included desktop computers, laptop word processors, scanners, digital cameras, video cameras, tape recorders, a largescreen "smart board" monitor, and the Internet. In fundamental ways, Lucy and Ann's lesson seemed to reflect the social constructivist theories underlying the design of the graduate class (Rogoff, 1990; Salomon \& Perkins, 1998; Wertsch, Del Rio, \& Alvarez, 1995, Vygotsky, 1978). Their project won praise from their university instructor and ultimately led to our choosing Lucy's classroom practice as the focus of this study.

\section{Lucy Moore}

In some ways, Lucy Moore is a victim of her own success. Her principal has come to count on her, not only as one of his building's select number of Vanguard teachers-ones who play a lead role in introducing technology into the curriculum-but as someone willing to take students into her classroom who have proved difficult to manage for other fourth-grade teachers at the school. During the fall semester, 12 new or internally transferred students replaced members of Lucy's original class of 30 . Five of these have special needs, and this circumstance proves challenging. Lucy explains

So, from the beginning of the school year, I molded my class and then all of a sudden the students that were in here were taken out, and then I received students that have these special needs. [The change] disrupted my class, my life-actually my personal life-because it is very tiring with five of them who are on medication, and you have to meet their needs.

Ninety-seven percent of First Street's 654 students qualify for federal free or reduced lunch, and Lucy's knowledge of her students'

Computers in the Schools, Vol. 23, No. 1-2 (September 08, 2006): pg. 73-84. DOI. This article is (C) Taylor \& Francis (Routledge) and permission has been granted for this version to appear in e-Publications@Marquette. Taylor \& Francis (Routledge) does not grant permission for this article to be further copied/distributed or hosted elsewhere without the express permission from Taylor \& Francis (Routledge). 
poverty and the meaning she attaches to it may shape her expectations. Lucy shares stories about the home lives of some of her students as a way of underscoring the difficulty she has teaching them fourth-grade material. Of one student in particular, she claims:

He's at a first grade level. He's a person who comes from a family that has seventeen children in their house who are all his cousins. His mom's coming in and out of his life, and she's not meeting the doctor's appointments so he is on medicine that we don't know what it is, and he's diving on the floor and that takes a lot of my teaching time out. I have foster children who don't know whose house they are going to be living in tonight.

Lucy feels burdened to be as much a "parent role model" as a teacher for her students. During the school day, Lucy presents lessons enthusiastically, her interactions with students are typically supportive and encouraging, and her enthusiasm for technology remains high in the semester after the graduate class. She believes that computers enhance learning and provide students with an enjoyable break from the monotony of teacher-led lessons. However, the mainstay of each day is teacher-led lessons from the fourth-grade texts. In white chalk on a black board at the front of the room, Lucy prints each day's lessons:

Morning Work-D.O.L. (Daily Oral Language)

Science

Social Studies-Definitions

Spelling-Lesson 5 def.

English-p. 65

Math-pages 41-42

\section{Using Technology}

Lucy teaches in a long rectangular classroom on the basement floor of First Street. Three rows of student desks fit easily across the length of the room. This arrangement facilitates easy viewing of the chalkboard, in front of which Lucy presents the majority of her lessons, but it complicates viewing of the TV monitor, mounted high on the sidewall, above Lucy's desk.

Computers in the Schools, Vol. 23, No. 1-2 (September 08, 2006): pg. 73-84. DOI. This article is (C) Taylor \& Francis (Routledge) and permission has been granted for this version to appear in e-Publications@Marquette. Taylor \& Francis (Routledge) does not grant permission for this article to be further copied/distributed or hosted elsewhere without the express permission from Taylor \& Francis (Routledge). 
When Lucy introduces a lesson that involves computer software, she can use the TV monitor to mirror the screen from her desktop computer. Students turn their chairs sideways and look up at the 27inch screen, but the quality of the display for the whole classroom is less than ideal. About half of Lucy's students sit within 15 feet of the TV monitor. The three who sit the farthest away are more than 25 feet from the screen. The principal acknowledges that the TV monitor is poorly placed in Lucy's classroom, but he also says that it will not be moved. Lucy could resolve this problem by asking to use the school's large-screen, Smart-Board monitor when she wants all students to be able to see the same computer screen during a lesson, but the principal says that the data projector for the SmartBoard is very sensitive and no one uses it much anymore. While Lucy does use an overhead projector during the fall semester and the side-mounted TV monitor many times, she does not elect to set up the SmartBoard for any lesson.

Lucy uses the TV monitor when she segues from a language arts lesson on possessives to a math lesson on statistics. Lucy begins the lesson on possessives by asking students questions about how many pets, cars, and bedrooms they have. She uses their answers to compose short sentences on the chalkboard that include a possessive noun or pronoun. Lucy enlists the students' help in deciding where to place apostrophes as she explains to them that possessives indicate ownership of something. When Lucy feels satisfied that students understand the language arts lesson, she asks them to turn their attention to the TV monitor on which a blank spreadsheet is displayed. She tells students about a "wonderful" program called "Excel" that they can use for an "easier way of finding out how many bedrooms we have."

The transition to the math lesson goes well at first. Lucy asks the students to pick out information from the sentences on the chalkboard that she can transfer to column headings on the spreadsheet. Lucy encourages students to help her correct typing errors in some of her entries by identifying the spreadsheet's cells by letter and number. "In cell A-1, 'children' is missing an 'i.' In cell B-1 'bedrooms' has an extra letter, 'a.'" The plan is to list several students' names under the "children" column and then to enter data about the

Computers in the Schools, Vol. 23, No. 1-2 (September 08, 2006): pg. 73-84. DOI. This article is (C) Taylor \& Francis (Routledge) and permission has been granted for this version to appear in e-Publications@Marquette. Taylor \& Francis (Routledge) does not grant permission for this article to be further copied/distributed or hosted elsewhere without the express permission from Taylor \& Francis (Routledge). 
number of bedrooms, pets, and cars each child has across the other three columns of the spreadsheet.

The lesson falters, however, when Lucy cannot transform the spreadsheet data into a graph. She moves from the monitor to one of the desktop computers at the back of the class, but she still cannot make the hoped-for transformation. She apologizes to the students, explaining that while the program had worked for her earlier, she would have to learn from her mistakes in the same way she always encourages them to do.

Lucy tries to make access to the seven computers at the back of the class equitable by assigning groups to each computer and rotating use among the members of the group. A lesson on punctuation, for instance, requires small groups of students to discuss how best to punctuate a sample sentence. One representative from each group types the sentence with the agreed-upon punctuation on its computer. Lucy will print out these responses and, in a follow-up activity, compare the results of each group's collective effort. Students can also use the classroom computers during recess and during designated study periods in the school day.

Lucy's students use computers most frequently, however, in one of First Street's two, 30-station Dell computer labs. In the third through fifth-grade computer lab, the lab supervisor manages student learning on a commercial software package that provides programmed instruction in reading, math, science discovery, and spelling skills. Each of the eleven, third-through fifth-grade groups spends 28 minutes a day in the lab. Lucy can elect to use this computer time for other purposes as she did during the semester she took the in-service course when she asked that students be allowed to work on their Freckle Juice projects. Her plans to make similar use of the lab time this year change when she adjusts to the principal's request that all First Street students enter the Martin Luther King, Jr., writing contest. Students use lab time originally intended for use on this year's book project to type the final drafts of their contest essays. Many of these essays feature the same characteristics. Each of three body paragraphs is devoted to one "hope for a better tomorrow"-the contest theme. Students learn to attend to the red and green

Computers in the Schools, Vol. 23, No. 1-2 (September 08, 2006): pg. 73-84. DOI. This article is (C) Taylor \& Francis (Routledge) and permission has been granted for this version to appear in e-Publications@Marquette. Taylor \& Francis (Routledge) does not grant permission for this article to be further copied/distributed or hosted elsewhere without the express permission from Taylor \& Francis (Routledge). 
underscored sections of their documents to correct spelling and grammatical errors.

In terms of technology integration, Lucy's fall semester book project repeats some and omits other student uses of technology from the previous spring's Freckle Juice project. One hardware application remains consistent. In addition to the classroom and lab computers, students use relatively inexpensive AlphaSmart Boards, lightweight keyboards that can store and automatically save up to 100 pages of single-spaced text in eight files, to word-process their assignments from hand-written drafts. Other similar student activities in the book project assignments include searching the Internet to find information about authors, making computer-generated crosswords or word puzzles from various vocabulary words, and selecting clip art for the picture book. Students do not, however, use the Internet to research thematic content as they did when they researched freckles, and they do not make or listen to tapes of book chapters or original compositions as they had for the Freckle Juice project assignments. Nor do they use digital or video cameras or create PowerPoint presentations to document their work for a public display.

Other differences include Lucy's decision to allow students to choose their own book instead of assigning Freckle Juice to the whole class and Lucy's not having Anne as a co-teacher to help plan, present, and guide the lesson; to assist with the technology integration; and to share the goal of presenting the results of their collaboration as their final project for the in-service course. Left alone to present the book project to her ever-changing group of 30 this year, Lucy has no one to echo the rallying cry, "You're going to love this! Wait till you see what we've got for you." Of last year's collaboration, Lucy says:

I think with doing it with someone else, yes it does help. . . . I don't have all the answers, and I don't know how I can help all my students with whatever needs they have, but having someone else working with me, of course, with the education that they have, or the background they have, working together makes it a lot easier. It wasn't so much the technology; it was actually getting the kids to do something that they were excited about. You know, to be able to show their talent writing something that's deep inside them.

Computers in the Schools, Vol. 23, No. 1-2 (September 08, 2006): pg. 73-84. DOI. This article is (C) Taylor \& Francis (Routledge) and permission has been granted for this version to appear in e-Publications@Marquette. Taylor \& Francis (Routledge) does not grant permission for this article to be further copied/distributed or hosted elsewhere without the express permission from Taylor \& Francis (Routledge). 
This time, the planned for exhibition to another teacher's class and the culminating personal interview do not take place; Lucy shuts the assignment down before all students finish, and she turns her attention to preparing students for the state achievement tests. When asked about the outcome of the book project, Lucy's star student, Carl, says:

I was on my tenth chapter and some of the kids in the class were on their first chapter. Then Ms. Moore got fed up with it, cause the kids weren't doing their jobs and so she made us stop. ... [The kids] thought it was just for fun, and they didn't want to do it. They thought it would go on forever, and they did not ... doit because they wanted to have fun playing the computers and ... games and stuff like that.

\section{Discussion}

What, then, is to be learned from this portrait of a fourth-grade teacher? In the semester following Lucy's completion of a graduate class intended to improve the way she uses technology for instruction and assessment, Lucy understands that she still is developing her repertoire of skills. Given time and practice, we presume that Lucy will get better at the technical proficiency she will need to move from spreadsheet to graph and back. Conceptually, however, Lucy's vision of how technology can improve the way students learn seems limited by what Tyack and Cuban (1995) have called "the grammar of schooling." Lucy plans her lessons to keep everyone more or less together. Students must complete 10 sentence, handwritten summaries of each chapter, for instance, before earning the right to move to the computer to transcribe them and correct mistakes in spelling and grammar. The process becomes mechanical, and achievement depends on the number of sentences just as much or more than on what the sentences say.

Lucy's characteristic assertion is that computers "enhance" student learning. When pressed to explain how computers enhance learning, she talks about the way students enjoy the break from having to listen to a teacher all day, or she will share an anecdote about how helpful the Internet is as a resource when students ask to learn more about a topic. The availability of computer technology does

Computers in the Schools, Vol. 23, No. 1-2 (September 08, 2006): pg. 73-84. DOI. This article is @ Taylor \& Francis (Routledge) and permission has been granted for this version to appear in e-Publications@Marquette. Taylor \& Francis (Routledge) does not grant permission for this article to be further copied/distributed or hosted elsewhere without the express permission from Taylor \& Francis (Routledge). 
not dramatically influence Lucy's basic methods or materials. She transmits the fourth-grade curriculum from assigned texts and relies on teacher-centered, question-and-response lessons, written homework, and tests to measure how much information students have retained.

Students use computers to word-process short papers and assignments and to search for information on the Internet. They report enjoying the drill-and-practice, skill-building software, and their principal rewards them with candy from his desk when they inform him that they have progressed to the next level of difficulty in math, reading, science, and spelling. Lucy does not like the computer games-Word Muncher and Math Blaster-that her students like so much, although she believes they do help students improve their basic skills. Lucy does not believe her group has the skills to make good use of Kidspiration, the graphical organizing software that she ordered for her students as a result of learning about it in the graduate class. She says she had hoped that her students would be ready to use the software to develop Web ideas as a prewriting exercise, but she does not believe her group this year has the ability for that application. In this instance, Lucy does seem to have low expectations for her students.

Whatever Lucy's expectations are, however, as long as the blackboard is easier to use and easier for students to see than the TV monitor, Lucy has little incentive to introduce lessons on a PowerPoint slide show, guide students to develop their own slide shows, or to master new software well enough to lead a brainstorming session with Kidspiration. While Lucy's principal expresses pride in the uses of technology he observes in classrooms throughout the building, he is more concerned that First Street's scores on the battery of state achievement tests improve each year. Those results make headlines in the metropolitan newspaper. Those results are posted on the district's Web site and invite comparisons among all elementary schools citywide and between the district's schools and all others throughout the state. Indeed, finding sufficient time to prepare students for the state tests contributes to Lucy's decision to end the book project before most students complete it.

Computers in the Schools, Vol. 23, No. 1-2 (September 08, 2006): pg. 73-84. DOI. This article is (C) Taylor \& Francis (Routledge) and permission has been granted for this version to appear in e-Publications@Marquette. Taylor \& Francis (Routledge) does not grant permission for this article to be further copied/distributed or hosted elsewhere without the express permission from Taylor \& Francis (Routledge). 
Despite the pressure to prepare students for the standardized tests, Lucy does not frame the problem as a false dilemma between innovative uses of the computer and programmed instruction. She knows how much students enjoy working on computers and wants to regain the "sparkle" she says she felt during the semester she took the course. Next year Lucy will be back with a new group of fourthgraders, and the school community will feel the burden of its label as one "needing improvement" in fourth-grade reading and math. One can imagine the pressure to do well on the next round of state tests will be palpable. How will Lucy respond? She sounds tentative. "I was sparkling last year when I took the course. This year it didn't work that way. Maybe next year . . . maybe a different project would be involved."

However, so many of the structures of and assumptions about schooling will stay the same. Merely redesigning the book project will not help Lucy resolve all the challenges to developing teaching practices that integrate technology in ways consistent with the student-centered, inquiry-based pedagogy the in-service course intended to impart (Schweizer, Whipp, \& Hayslett, 2002). When asked to imagine an ideal use of computer technology, Lucy talks about being able to present fourth-grade material to well-behaved students who can submit completed homework assignments to her computer where the work will be averaged automatically.

\section{Conclusion}

Certainly, a professional development course is just one variable in a complex equation which has as its solution, transformative teaching-an equation with few constants and many unknowns, an equation requiring massive resources and critical new perspectives. The challenges Lucy faces and the way she faces them represent a unique set of experiences, certainly, but not a unique set of challenges. Student mobility and special needs, unexpected administrative mandates, lack of teacher collaboration, anxiety of being judged as competent based on standardized test results, poorly designed classrooms, insufficient time to master new software, lowexpectations, and habitual ways of conceptualizing what and how students should learn-all complicate efforts to help students use

Computers in the Schools, Vol. 23, No. 1-2 (September 08, 2006): pg. 73-84. DOI. This article is (C) Taylor \& Francis (Routledge) and permission has been granted for this version to appear in e-Publications@Marquette. Taylor \& Francis (Routledge) does not grant permission for this article to be further copied/distributed or hosted elsewhere without the express permission from Taylor \& Francis (Routledge). 
computers to construct meaning and represent their learning to others. Lucy's experience poses legitimate challenges to the designers of in-service courses who hope to promote the value of integrating technology in ways consistent with social constructivist theory and student-centered pedagogy. A successful collaborative project within the context of such a graduate course is only as strong as the collaboration. When Anne and Lucy return to their normal teaching lives, they do not share the onus of having to perform for classmates or an instructor. Other concerns and more familiar priorities and habits consume their energies.

Implications for future research abound. Will case studies of other successful participants in courses similar to Using Technology for Instruction and Assessment reveal similar challenges? How can such courses address challenges like the ones Lucy faces? Given the power of what Cuban (1993, p. 186) describes as the "cultural beliefs about what teaching is, how learning occurs, what knowledge is proper in schools, and the teacher-student (not student-machine) relationship [that] dominate popular views of proper schooling," what can any inservice course on technology integration hope to accomplish when changing those beliefs is at the heart of its purpose?

\section{References}

Cuban, L. (1993). Computers meet classroom: Classroom wins. Teachers College Record, 95(2), 185-211.

Handler, M., \& Strudler, N. (1997). The ISTE Foundation Standards: Issues of implementation. Journal of Computing in Teacher Education, 13(2), 16-23.

Middlebrooks, T., Schweizer, H., Frederick, G., Jonas, P. G., \& Swope, K. (2002, April). Growing technology literate teachers: Affective means to effective ends. Paper presented at the American Educational Research Association Annual Convention, New Orleans.

Roblyer, M.D., \& Edwards, J. (2000). Integrating educational technology into teaching (3rd ed.). Upper Saddle River, NJ: Prentice Hall.

Rogoff. B. (1990). Cognitive apprenticeship: Cognitive development in social context. New York: Oxford University Press.

Salomon, G., \& Perkins, D. N. (1998). Individual and social aspects of learning. In P. D. Pearson \& A. Iran-Nejad (Eds.), Review of Research in Education, 23, 1-24.

Computers in the Schools, Vol. 23, No. 1-2 (September 08, 2006): pg. 73-84. DOI. This article is (C) Taylor \& Francis (Routledge) and permission has been granted for this version to appear in e-Publications@Marquette. Taylor \& Francis (Routledge) does not grant permission for this article to be further copied/distributed or hosted elsewhere without the express permission from Taylor \& Francis (Routledge). 
NOT THE PUBLISHED VERSION; this is the author's final, peer-reviewed manuscript. The published version may be accessed by following the link in the citation at the bottom of the page.

Schrum, L. (1999). Technology professional development for teachers. Educational Technology Research and Development, 47(4), 83-90.

Schweizer, H., Whipp, J., \& Hayslett, C. (2002). Quality control in online courses: Using a social constructivist framework, Computers in the Schools, 19 (3/4), 143-158.

Sheingold, K., \& Hadley, M. (1990). Accomplished teachers: Integrating computers into classroom practice. New York: Bank Street College of Education.

Tyack, D., \& Cuban, L. (1995). Tinkering toward utopia: A century of public school reform. Boston: Harvard University Press.

Vygotsky, L. (1978). Mind in society: The development of higher psychological processes. Cambridge, MA: Harvard University Press.

Wertsch, J.V., Del Rio, P., \& Alvarez, A. (Eds.). (1995). Sociocultural studies of mind. New York: Cambridge University Press.

Whipp, J., \& Schweizer, H. (2001). Meeting psychological needs in Web based courses for teachers. Journal of Computing and Teacher Education, $17(1), 26-31$.

Computers in the Schools, Vol. 23, No. 1-2 (September 08, 2006): pg. 73-84. DOI. This article is (C) Taylor \& Francis (Routledge) and permission has been granted for this version to appear in e-Publications@Marquette. Taylor \& Francis (Routledge) does not grant permission for this article to be further copied/distributed or hosted elsewhere without the express permission from Taylor \& Francis (Routledge). 